\title{
Energetic potential of bamboo culms for industrial and domestic use in Southern Brazil
}

\author{
Potencial energético de colmos de bambu para uso \\ industrial e doméstico na região sul do Brasil
}

\begin{abstract}
Ailton Leonel Balduino Junior ${ }^{\mathrm{I}}$ Thalles Yurgen Balduino ${ }^{\mathrm{II}}$ Gustavo Friederichs ${ }^{\text {II }}$ Alexsandro Bayestorff da Cunha ${ }^{\mathrm{III}}$ Martha Andreia Brand ${ }^{\mathrm{II}}{ }^{*}$
\end{abstract}

\section{ABSTRACT}

This study aimed to determine the energetic quality of the Bambusa vulgaris culms for combustion (in natura) and as a charcoal. Five individuals (culms) of Bambusa vulgaris of 3 years of age were analyzed, gathered in the city of Florianópolis, Santa Catarina. In the in natura culms it was determined the moisture content freshly gathered (39\%); basic density $\left(0.624 \mathrm{gcm}^{-3}\right)$; the chemical composition (total extractive content (16.26\%) and lignin content $(25.76 \%))$; the proximate chemical composition (volatiles content (82.25\%); fixed carbon content (15.26\%) and ash (2.49\%)) and gross calorific value $\left(4571 \mathrm{kcalkg}^{-1}\right)$. In the charcoal, produced in the laboratory, the determined properties were the gravimetric yield (36.40\%); the apparent density $\left(0.372 \mathrm{gcm}^{-3}\right)$; volatiles content (27.55\%); fixed carbon content (67.32\%); ash (5.12\%) and gross calorific value $\left(7431 \mathrm{kcalkg}^{-1}\right)$. The Bambusa vulgaris species has potential for use in the energy generation either in natura, as chips for burning in boilers or in the charcoal form for domestic use, it can be used to broaden the base of biomass for energy generation and to replace the timber species of Pinus and Eucalyptus gender used for this purpose in the Southern region of Brazil.

Key words: Bambusa vulgaris, biomass energy, chips for boiler, charcoal.

\section{RESUMO}

Este trabalho teve como objetivo determinar a qualidade energética de colmos de Bambusa vulgaris para queima direta (in natura) e na forma de carvão vegetal. Foram analisados cinco individuos (colmos) de Bambusa vulgaris com 3 anos de idade, coletados na cidade de Florianópolis, Santa Catarina. Nos colmos in natura foram determinados o teor de umidade recém coletado (39\%); massa especifica básica $\left(0,624 \mathrm{gcm}^{-3}\right) ; a$ composição química (teor de extrativos totais (16,26\%) e teor de lignina (25,76\%)); a composição química imediata(teor de voláteis (82,25\%); teor de carbono fixo (15,26\%) e cinzas (2,49\%)) e poder calorífico superior $\left(4571 \mathrm{kcalkg}^{-1}\right)$. No carvão vegetal, produzido em laboratório, foram determinados o rendimento gravimétrico $(36,40 \%) ;$ a densidade aparente $\left(0,372 \mathrm{gcm}^{-3}\right)$; teor de voláteis (27,55\%); teor de carbono fixo (67,32\%); cinzas $(5,12 \%)$ e poder calorifico superior $\left(7431 \mathrm{kcalkg}^{-1}\right)$. A espécie Bambusa vulgaris tem potencial para utilização na geração de energia tanto na forma in natura, como cavacos para a queima em caldeiras, como na forma de carvão vegetal para uso doméstico, podendo ser utilizada para ampliar a base de biomassa para geração de energia e ate substituir as espécies madeireiras do gênero Pinus e Eucalyptus utilizadas para este fim na região sul do Brasil.

Palavras-chave: Bambusa vulgaris, energia de biomassa, cavacos para caldeira, carvão vegetal.

\section{INTRODUCTION}

In 2011, it was established in Brazil the Law n. 12.484, which regulates the national policy to encourage sustainable management and the cultivation of Bamboo (PNMCB). This law aims the development of bamboo culture in Brazil through government actions and private enterprises. Among other actions, the federal government intends to work on the implementation of the incentive for research and technological development focused on sustainable management, cultivation, environmental services and applications of

IPrograma de Pós-graduação em Engenharia Florestal, Centro de Ciências Agroveterinárias, Universidade do Estado de Santa Catarina (UDESC), Lages, SC, Brasil.

${ }^{\text {IIC }}$ urso de graduação em Engenharia Florestal, Centro de Ciências Agroveterinárias, Universidade do Estado de Santa Catarina (UDESC), Lages, SC, Brasil.

"IIDepartamento de Engenharia Florestal, Centro de Ciências Agroveterinárias, Universidade do Estado de Santa Catarina (UDESC), Av. Luiz de Camões, 2090, 88520-000, Lages, SC, Brasil. E-mail: martha.brand@udesc.br. "Corresponding author. 
the products and bamboo by-products; encourage the cultivation and the use of bamboo by family farming, stimulate the internal and external market of bamboo and its by-products (BRASIL, 2011).

In Brazil, the bamboo species are found in almost all regions, either at sea level as in the mountainous regions (PRESZNHUK, 2004). Beyond that, there is potential for planting native and exotic species of bamboo. Relative to the exotics, the species with the greatest potential are Dendrocalamus giganteus, D. Latiflorus e D. asper, and the genders Phyllostachyse Bambusa. In the gender Bambusa, one of the species with greatest economic importance is the Bambusa vulgaris, used in the production of bioenergy (charcoal) cellulose and paper (GRECO \& CROMBERG, 2011; GUARNETTI, 2013), being in the list of the priority species of bamboo for research in the world (NATIONAL TROPICAL BOTANICAL GARDEN, 2014). Greater attention has been given to Bambusa vulgaris due to the high growth rate, the short renewal period under various conditions of soil and climate and the easy propagation (SUN et al., 2013).

The Bambusa vulgaris is originally from Asia and came to Brazil brought by the Portuguese, widespread in the country and used on farms for several purposes. According to GUARNETTI (2013), in the Northeast, the João Santos group has a production of 30 thousands hectares of Bambusa vulgaris for biomass use, and the Penha group explores 3 thousands hectares meant for energy purposes, where biomass is used in the form of chips, burned in boiler.

Bamboo species are potential candidates for bioenergy production, due to its high content of cellulose and hemicellulose, high gross calorific value and low ash content, constituting promising energy cultures for use in biorefineries, in Brazil (RAMBO et al., 2015).

However, in southern Brazil, the area of bamboo plantations bamboo are small, and in regions where there is nofrost, as the coastal region, the Bambusa vulgaris is a promising species, but it requires technical information to support investors who are interested in expanding the supply base of biomass for energy generation in this region.

Considering that in Southern Brazil, the biomass for energy generation is basically coming from species of Pinus and Eucalyptus gender and that besides the energy supply chain, these species may be present in other production chains (cellulose and paper and mechanical transformation), the inclusion of bamboo can be strategic in the segments of the energy use of biomass, as in the industry (use in natura as chips in boilers) and in domestic use as charcoal for cooking and heating (fireplace).

In this context, the determination of the energetic quality of this biomass is important to strengthen its use as a reliable energetic source in southern Brazil. Thus, this study aimed to determine the energetic quality of culms of Bambusa vulgaris for combustion (in natura) and as charcoal.

\section{MATERIALS AND METHODS}

Five individuals (culms) of Bambusa vulgaris of 3 years of age were analized, gathered in the Experimental Farm Ressacada of the Federal University of Santa Catarina, in Florianópolis (27\%41'03.7'S 48'32'33.8'W). Each individual had the $\mathrm{DBH}$ and the total high measured $(9.0 \mathrm{~cm}$ and $18.0 \mathrm{~m}, 10.5 \mathrm{~cm}$ and $13.0 \mathrm{~m}, 7.3 \mathrm{~cm}$ and $12.0 \mathrm{~m}, 10.5 \mathrm{~cm}$ and $16.0 \mathrm{~m}$ and $11.0 \mathrm{~cm}$ and $16.5 \mathrm{~m} \mathrm{DBH}$ and total height, respectively), and portions of $1 \mathrm{~m}$ of length were collected at the base, middle and top of the culms. The energetic quality of the specie was analized in natura and after the charcoal production. Samples were made from the culms in natura to determine the basic density (BD), using the maximum moisture content method, according to the equation 1 :

$G_{f}=\frac{1}{\left(\frac{M_{m}-0,346}{M_{o}}\right)}$

where: $M_{m}$ is the mass of water-saturated wood in grams after the removal of the surface water with a damp cloth, $\left(\mathrm{gcm}^{-3}\right) ; \mathrm{M}_{\mathrm{o}}$ is the oven dry weight, achieved by oven drying at $105^{\circ} \mathrm{C} \pm 3^{\circ} \mathrm{C}$ until constant weight $\left(\mathrm{g} \mathrm{cm}^{-3}\right) ; 1 / \mathrm{G}_{\mathrm{s}}=0.346$, assuming that the average density of the wood substance is $1.53 \mathrm{~g} \mathrm{~cm}^{-3}$.

After obtaining samples, excess of material was ground in a hammer mill and from de sawdust a sample was gathered to determine the moisture content (MC). The remaining material was placed in a climatic chamber. For the energetic and chemical analyses of sawdust, the material used was the one which remained in the 60 mesh sieve. Physical, chemical and energetic analyzes of in natura material are in table 1, along with the used standards and the experimental design adopted in the study.

The same samples used for the determination of the basic density were wrapped in aluminium foil and charred in a laboratory muffle, without air intake. Carbonization was the total time of 6 hours and 30 minutes with a final temperature of $450^{\circ} \mathrm{C}$ in the last 30 minutes, heating rate variable and descending along the carbonization. 
Table 1 - Standards used to determine the physical and energetic properties in culms of Bambusa vulgaris.

\begin{tabular}{llccc}
\hline Analized propertie & \multicolumn{1}{c}{ Standard } & N & NP & Total \\
\hline Moisture Content & NBR 14929 (ABNT, 2003) & 5 & 3 & 3 \\
Basic density & Maximum Moisture Content method & 5 & 3 & 10 \\
Gross calorific value & DIN 51900 (DIN, 2000) & 5 & 1 & 150 \\
Proximate analysis & ASTM 1762 (ASTM, 2013) & 5 & 1 & 3 \\
Chemical analysis & NBR 7989 (ABNT, 2010) & 5 & 1 & 4 \\
\hline
\end{tabular}

$\mathrm{N}=$ number of individuals analyzed; $\mathrm{NP}=$ number of positions (3: base, middle and top; 1 : for the mixing of the three positions); $\mathrm{R}=$ number of repetitions for each property analyzed in each position and individual.

After de carbonization, the apparent density of the charcoal was determined, through the volume and weight measurements of the specimens, and the gravimetric yield of carbonization by the reaction between the dry weight of charcoal and the absolutely dry weight of the specimen, before carbonization. The charcoal was ground and used for the determination of: moisture content, according to the standard NBR 14929 (ABNT, 2003), gross calorific value, according to the standard DIN 51900 (DIN, 2000 ) and the proximate analysis according to the standard ASTM 1762 (ASTM, 2013).

The F-test was applied to check the variation between the treatments and then the Tukey test at $5 \%$ of probability.

\section{RESULTS AND DISCUSSION}

The moisture content of the evaluated species is close to the desired maximum for the energy generation that is $30 \%$ (Table 2), constituting an advantage when using the culms for direct burning, with statistically significant differences between the evaluated individuals. For mature culms of this species, with more than three years, ROUSSET et al. (2011) reported values of $20.19 \%$ of humidity.

Timber species, such as the gender Eucalyptus and Pinus, are commonly used for energy generation in the study area, in southern Brazil. These in turn, show high moisture content in freshly harvested material, compared to bamboo. BRAND (2013) analyzing the logs moisture content

Table 2 - Physical and chemical properties of culms in natura and charcoal of Bambusa vulgaris.

\begin{tabular}{|c|c|c|c|c|c|c|}
\hline \multirow{2}{*}{ Culms in natura } & \multicolumn{5}{|c|}{-Analized Individuals---- } & \multirow{2}{*}{ Mean } \\
\hline & 1 & 2 & 3 & 4 & 5 & \\
\hline $\mathrm{MC}(\%)$ & $34 \mathrm{c}$ & $36 \mathrm{c}$ & $54 \mathrm{a}$ & $39 \mathrm{~b}$ & $31 \mathrm{~d}$ & 39 \\
\hline $\mathrm{BD}\left(\mathrm{gcm}^{-3}\right)$ & $0.752 \mathrm{a}$ & $0.612 \mathrm{~b}$ & $0.403 \mathrm{~d}$ & $0.678 \mathrm{c}$ & $0.676 \mathrm{bc}$ & 0.624 \\
\hline TE $(\%)$ & $16.52 \mathrm{a}$ & $16.22 \mathrm{a}$ & $15.46 \mathrm{a}$ & $16.37 \mathrm{a}$ & $16.71 \mathrm{a}$ & 16.26 \\
\hline L (\%) & $25.79 \mathrm{a}$ & $25.74 \mathrm{a}$ & $25.80 \mathrm{a}$ & $25.75 \mathrm{a}$ & $25.60 \mathrm{a}$ & 25.76 \\
\hline $\mathrm{FC}(\%)$ & $16.31 \mathrm{a}$ & $14.21 \mathrm{a}$ & $15.07 \mathrm{a}$ & $15.74 \mathrm{a}$ & $14.96 \mathrm{a}$ & 15.26 \\
\hline VC (\%) & $82.49 \mathrm{a}$ & $82.40 \mathrm{a}$ & $81.98 \mathrm{a}$ & $82.54 \mathrm{a}$ & $81.87 \mathrm{a}$ & 82.25 \\
\hline $\mathrm{AC}(\%)$ & $1.19 \mathrm{~b}$ & $3.39 \mathrm{a}$ & $2.95 \mathrm{a}$ & $1.72 \mathrm{~b}$ & $3.17 \mathrm{a}$ & 2.49 \\
\hline GCV $\left(\right.$ kcalkg $\left.^{-1}\right)$ & $4585 \mathrm{~b}$ & $4702 \mathrm{a}$ & $4599 a b$ & $4452 \mathrm{c}$ & $4517 \mathrm{bc}$ & 4571 \\
\hline Charcoal & 1 & 2 & 3 & 4 & 5 & Mean \\
\hline $\mathrm{AD}\left(\mathrm{gcm}^{-3}\right)$ & $0.415 \mathrm{~b}$ & $0.345 \mathrm{c}$ & $0.258 \mathrm{~d}$ & $0.382 \mathrm{bc}$ & $0.463 \mathrm{a}$ & 0.372 \\
\hline GY (\%) & $34.38 \mathrm{~d}$ & $36.49 \mathrm{bc}$ & $38.10 \mathrm{a}$ & $35.74 \mathrm{c}$ & $37.31 \mathrm{ab}$ & 36.40 \\
\hline $\mathrm{VC}(\%)$ & $27.31 \mathrm{~b}$ & $26.68 \mathrm{~b}$ & $30.72 \mathrm{a}$ & $27.33 \mathrm{~b}$ & $25.73 \mathrm{~b}$ & 27.55 \\
\hline $\mathrm{FC}(\%)$ & $68.63 \mathrm{a}$ & $67.52 \mathrm{a}$ & $62.99 \mathrm{~b}$ & $68.48 \mathrm{a}$ & $69.01 \mathrm{a}$ & 67.32 \\
\hline $\mathrm{AC}(\%)$ & $4.06 \mathrm{c}$ & $5.81 \mathrm{a}$ & $6.30 \mathrm{a}$ & $4.19 \mathrm{cb}$ & $5.26 \mathrm{ab}$ & 5.12 \\
\hline GCV $\left(\right.$ kcalkg $\left.^{-1}\right)$ & $7568 \mathrm{a}$ & $7340 \mathrm{ab}$ & $7207 \mathrm{~b}$ & $7507 \mathrm{ab}$ & $7532 \mathrm{ab}$ & 7431 \\
\hline
\end{tabular}

Note: Means IN LINE followed by the same letter do not differ statistically between them at $5 \%$ of probability by Tukey test.

Abbreviations: $\mathrm{MC}=$ wet basis moisture content; $\mathrm{BD}=$ basic density; $\mathrm{TE}=$ total extractives; $\mathrm{L}=$ lignin content; $\mathrm{FC}=$ fixed carbon content; $\mathrm{VC}=$ volatiles content; $\mathrm{AC}=$ ash content; $\mathrm{GCV}=$ gross calorific value; $\mathrm{AD}=$ apparent density; $\mathrm{GY}=$ gravimetric yield. 
of Pinus taeda (loblolly pine) and Eucalyptus dunnii (white gum) meant to energy generation, harvested at different times of the year, observed values ranging from 55 to $65 \%$, with an average of $59 \%$ for pine with bark and 50 to $58 \%$ with an average of $54 \%$ of humidity for eucalyptus logs with bark freshly harvested, in the South of Brazil.

The basic density mean of Bambusa vulgaris culms can be classified as medium and it was similar to the values obtained by other authors, including the statistical variation that occurred between individuals of the same species. For culms of approximately four years of age, MELO et al. (2015) obtained $0.630 \mathrm{gcm}^{-3}$. MOREIRA (2012) obtained average values of $0.646 \mathrm{gcm}^{-3}$, while BRITO et al. (1987) reported $0.687 \mathrm{gcm}^{-3}$, for the three years of age individuals. Compared to timber species used for energy generation, the density of Bambusa vulgaris is similar to those reported by PROTÁSIO et al. (2011) ranging from $0.471 \mathrm{gcm}^{-3}$ to $0.619 \mathrm{gcm}^{-3}$ for different species of Eucalyptus sp.

The extractive and lignin content were high, with no significant variation among the evaluated individuals. Values observed were compatible with other authors. Regarding to the extractives, BRITO et al. (1987) obtained $16.2 \%$ of total extractives. For the lignin content, RAMBO et al. (2015) obtained $17.60 \%$ and MACEDO et al. (2014) reported 25.8\%, of total lignin, for the one year of age species; ROUSSET et al. (2011) obtained 26.65\% of lignin, for culms with more than three years; and for the age of three years, MOREIRA (2012) reported 23.11\% and BRITO et al. (1987) 17.5\%.

Comparing the bamboo and wood chemical composition, the bamboo has higher extractives content, and lower lignin content. BASSA et al. (2007) obtained values of $2.37 \%$ and $2.50 \%$ for total extractives and $31.18 \%$ and $28.54 \%$ for lignin content for Pinus taeda and for the hybrid Eucalyptus grandis $x$ E. uroplylla, respectively.

The chemical composition characterized by larger amounts of extractives is positive for the energy generation, since these components have a higher calorific value compared to cellulose and polyoses, giving biomass a higher gross calorific value. However, lower lignin contents implies in a reduction of calorific value.

The volatile content was higher when compared to that observed by authors like MACEDO et al. (2014),which analyzed the volatile content of the species with one year of age and obtained $78.30 \%$; RAMBO et al. (2015) obtained $81.08 \%$, MOREIRA (2012) $78.14 \%$ and ROUSSET et al.
(2011) $80.13 \%$. Conversely, the fixed carbon values were lower when compared to that reported by other authors: $17.20 \%$ (RAMBO et al., 2015); 19.60\% (MACEDO et. al., 2014); 17.67\% (MOREIRA, 2012); 17.75\% (ROUSSET et al., 2011). Both, volatiles and fixed carbon did not show a statistical variation between the individuals.

The ash content values obtained by ROUSSET et al. (2011) were $2.12 \%$ and RAMBO et al. (2015) obtained $1.71 \%$. According to MOREIRA (2012), the ash content tends to rise with the increasing of the age due to the accumulation of siliceous bodies. There was statistical variation between the individuals analyzed, constituting two groups of similarity.

Considering the energy use, the wood showed material volatile content between 75 and $85 \%$, and fixed carbon content between 15 to $25 \%$. Therefore, the bamboo had higher ash content, and volatile content equivalent to that observed for different wood species and groups. Thus, the bamboo can be considered of rapid combustion, where most of its mass is burned in the form of gases and the smallest proportion in the solid form (residual carbon).

The gross calorific value of Bambusa vulgaris can be considered similar to that obtained by others authors: $4378 \mathrm{kcalkg}^{-1}$ (RAMBO et al., 2015); 4000kcal. $\mathrm{kg}^{-1}$ (GUANNETTI, 2013); $4370 \mathrm{kcalkg}^{-1}$ (MOREIRA, 2012) and 4216 $\mathrm{kcalkg}^{-1}$ (BRITO et.al, 1987). QUIRINO et al. (2005) evaluating the calorific value of different timber species reported values between 3888 and $5263 \mathrm{kcalkg}^{-1}$, wherefore the bamboo is within the values observed for wood. There was statistical difference among the analyzed individuals.

The apparent density of the Bambusa vulgaris charcoal was highly variable among the analyzed individuals, showing from low to high values of density, 0.258 to $0.463 \mathrm{gcm}^{-3}$. According to BRITO et al. (1987), the value of the apparent density of Bambusa vulgaris charcoal was $0.418 \mathrm{gcm}^{-3}$. The highest basic density values, presented by bamboos, are highly favourable in terms of their use for charcoal production because they will result in denser coals, which is desirable in terms of quality of this product (BRITO et al., 1987).

The gravimetric yield (GY) was high, with a lot of variation between the individuals. XIONG et al. (2014) observed a yield around 31\% for bamboo carbonization with a temperature of $450^{\circ} \mathrm{C}$. MAIA et al. (2013), for the same temperature, producing charcoal with Phyllostachys aurea obtained GY of $34.3 \%$. COSTA (2004) obtained 32.54\%; however, the average maximum temperature used in the 
carbonization was $400^{\circ} \mathrm{C}$. BRITO et al. (1987) obtained the average value of GY of $29.6 \%$, with a final temperature of $550^{\circ} \mathrm{C}$.

The volatile content for the charcoal was high, compared to those observed by MACEDO et al. (2014) when they examined the volatile content of the Bambusa vulgaris of one year of age, which was $21.30 \%$. XIONG et al. (2014) reported 22\%; MAIA et al. (2013) $36.5 \%$; COSTA (2004) $16.00 \%$; and BRITO et al. (1987) $16.75 \%$. Only the third individual was statistically different from the others. High values of volatile content may be related to the carbonization ramp used, since the temperature, the carbonization rate and the time of the carbonization influence the quality of the charcoal obtained (COSTA, 2004).

The fixed carbon content was low for charcoal, compared to the literature values and showed a statistical difference just between the third individual and the others. MACEDO et al. (2014) obtained 78.30\%; COSTA (2004) 78.00\%, and BRITO et al. (1987) $86.30 \%$. Only XIONG et al. (2014) and MAIA et al. (2013) reported lower values than those presented, $65 \%$ and $57.4 \%$, respectively.

The average ash content was high, and with a lot of variation among the individuals, compared to the results of Maia et al. (2013) (2.7\%); COSTA (2004) (3.28\%); BRITO et al. (1987) (3.5\%). Only XIONG et al. (2014) reported $13 \%$ of ash content.

ZANUNCIO et al. (2014) determined for charcoal of various species of Eucalyptus the values 19.33 to $26.93 \%$ of volatiles; 72.70 to $80.22 \%$ of fixed carbon, 0.21 to $1.88 \%$ of ashes, demonstrating that the quality of the charcoal obtained from Bambusa vulgaris, in the carbonization ramp adopted, was low regarding to the proximate chemical composition.

The gross calorific value of Bambusa vulgaris charcoal was high. The values obtained in the literature ranged from $7969 \mathrm{kcalkg}^{-1}$ (COSTA, 2004) to $7785 \mathrm{kcalkg}^{-1}$ (BRITO et al., 1987), being higher than those observed in this study.

\section{CONCLUSION}

The energetic quality of bamboo culms, either in natura or in charcoal form is similar to other species traditionally used for energetic generation in the study region.

The Bambusa vulgaris species has potential for use in the energy generation either in natura as chips, for burning in industrial boilers, or in the form of charcoal for domestic use. Besides that, the species can be used to increase the base of biomass for energy generation and even to replace the timber species used for this purpose in the study region.

\section{ACKNOWLEDGMENTS}

To Conselho Nacional de Desenvolvimento Científico e Tecnológico (CNPQ), Associação Catarinense do Bambu - Bambu SC and the Universidade Federal de Santa Catarina (UFSC).

\section{REFERENCES}

AMERICAN SOCIETY FOR TESTING AND MATERIAL (ASTM). ASTM 1762: Standard Test Method for Chemical Analysis of Wood Charcoal.West Conshohocken, PA: ASTM International, 2013. 2p.

ASSOCIAÇÃO BRASILEIRA DE NORMAS TÉCNICAS (ABNT). NBR 14929: Madeira - Determinação do teor de umidade de cavacos - Método por secagem em estufa. Rio de Janeiro, 2003. 3p.

ASSOCIAÇÃO BRASILEIRA DE NORMAS TÉCNICAS (ABNT). NBR 7989: Pasta celulósica e madeira - Determinação de lignina insolúvel em ácido. Rio de Janeiro, 2010. 6p.

BASSA, A.G.M.C et al. Misturas de madeira de Eucalyptus grandis x Eucalyptus urophylla e Pinus taeda para produção de celulose Kraft através do Processo Lo-Solids. Scientia Forestalis, v.75, p.19-29, 2007. Available from: <http://www.ipef.br/ publicacoes/scientia/nr75/cap02.pdf>. Accessed: Feb. 15, 2016.

BRAND, M.A. Influência da espécie na qualidade da biomassa florestal sob estocagem, para geração de energia. Ambiência, v.9, n.3, p.461-474, 2013. Available from: $<$ http://revistas.unicentro.br/ index.php/ambiencia/issue/view/190>. Accessed: Dec. 10, 2015. doi: 10.5935/ambiencia.2013.03.01.

BRASIL. Lei $\mathbf{n}^{\circ} \mathbf{1 2 . 4 8 4} 8$ de setembro de 2011. Available from: $<$ https://www.planalto.gov.br/ccivil_03/_ato2011-2014/2011/lei/ 112484.htm>. Accessed: Jun. 12, 2015.

BRITO, J.O. et al. Produção e caracterização do carvão vegetal de espécies e variedades de bambu. IPEF, n.36, p.13-17, 1987. Available from: <https://www.agencia.cnptia.embrapa.br/ Repositorio/carvaovegetal4_000g7duvaya02wx5ok0wtedt3gnh0u tf.pdf>. Accessed: Dec. 05, 2015.

COSTA, T.M.S. Estudo da viabilidade técnica do emprego do bambu da espécie Bambusa vulgaris Shard. como carvão vegetal. 2004. 74f. Dissertation (Master in Science in the Technology Area of Nuclear-Materials) -University of São Paulo, São Paulo, SP.

DEUTSCHES INSTITUT FÜR NORMUNG (DIN). DIN 51900: determining the gross calorific value of solid and liquid fuels using the bomb calorimeter, and calculation of net calorific value. Berlim, 2000. 7p.

GRECO, T.M.; CROMBERG, M. Bambu: cultivo e manejo. Florianópolis: Insular, 2011.1181p.

GUARNETTI, R.L. Cogeração de eletricidade utilizando bambu no Brasil: aspectos técnicos econômicos e ambientais. 2013.156f. Thesis (Doctorate)- University of São Paulo, SP. 
MACEDO, L.A. et al. Influência da composição da biomassa no rendimento em condensáveis da torrefação de resíduos vegetais Pesquisa Florestal Brasileira, v.34, n.80, p.417-424, 2014. Available from: <http://pfb.cnpf.embrapa.br/pfb/index.php/pfb/article/view/747>. Accessed: Nov. 08, 2015. doi: 10.4336/2014.pfb.34.80.747.

MAIA, C.M.B.D.F. et al. Efeito da temperatura de carbonização sobre características físico-químicas dos carvões de duas espécies de bambu. In: ENCONTRO BRASILEIRO DE SUBSTÂNCIAS HÚMICAS, 10., 2013, Santo Antônio de Goiás, Goiás. Anais... Brasília, DF: Embrapa, 2013.

MELO, R.R.D.et al. Physical mechanical properties of wood-bamboo particleboard. Ciência Rural, v.45, n.1, p.35-42, 2015. Available from: $<$ http://www.scielo.br/pdf/cr/v45n1/0103-8478-cr-45-01-00035.pdf>. Accessed: Feb. 10, 2016. doi: 10.1590/0103-8478cr20120970.

MOREIRA, A.C.O. Caracterização de Bambusa vulgaris Schard. exj.c. wendl. var. vulgaris, e dos resíduos de caldeira no processo de conversão térmica de energia. 2012. 61f. Dissertation (Postgraduate Program in Forest Engineering) - University of Brasília, DF.

NATIONAL TROPICAL BOTANICAL GARDEN. Bambusa vulgaris: Schrad. ex JC Wendl.- bamboo comum. Available from: $\quad<$ http://ntbg.org/plants/plant_details.php?plantid=11810 . Accessed: Nov. 08, 2015.

PRESZNHUK, R.A.D.O. Estudo da viabilidade do filtro de carvão de bambu como pós-tratamento em estação de tratamento de esgoto por zona de raízes: tecnologia ambiental e socialmente adequada. 2004. 109 f. Dissertation (Postgraduate Program in Technology) - CEFET/PR
PROTÁSIO, T. de P. et al. Compactação de biomassa vegetal visando à produção de biocombustíveis sólidos. Pesquisa Florestal Brasileira, v.31, n.68, p.273, 2011. Available from: <http://pfb. cnpf.embrapa.br/pfb/index.php/pfb/article/view/288>. Accessed: Dec. 06, 2015. doi: 10.4336/2011.pfb.31.68.273.

QUIRINO, W.F. et al. Poder calorífico da madeira e de materiais lignocelulósicos. Revista da Madeira, v.89, p.100-106, 2005.

RAMBO, M.K.D. et al. Analysis of the lignocellulosic components of biomass residues for biorefinery opportunities. Talanta, v.144, p.696-703, 2015. Available from: <http://www.sciencedirect.com/ science/article/pii/S0039914015300862>. Accessed: Dec. 07, 2015. doi: 10.1016/j.talanta.2015.06.045

ROUSSET, P. et al. Enhancing the combustible properties of bamboo by torrefaction. Bioresource Technology, v.102, n.17, p.8225-8231, 2011. Available from: <http://www.sciencedirect. com/science/article/pii/S0960852411008005>. Accessed: Dec. 08, 2015. doi: 10.1016/j.biortech.2011.05.093

SUN, Z.Y. et al. Reduction in environmental impact of sulfuric acid hydrolysis of bamboo for production of fuel ethanol. Bioresource technology, v.128, p.87-93, 2013. Available from: <http://www. sciencedirect.com/science/article/pii/S0960852412015842>. Accessed: Dec. 08, 2015. doi: 10.1016/j.biortech.2012.10.082.

ZANUNCIO, A.J.V. et al. Secagem ao Ar Livre da madeira para produção de carvão vegetal. Floresta e Ambiente, v.21, n.3, p.401-408, 2014. Available from: <http://www.floram. org/files/v21n3/v21n3a14.pdf $>$. Accessed: Dec. 08, 2015.doi: $10.1590 / 2179-8087.028713$. 